\title{
Strategic manufacturing priorities for South African manufacturers: the need to shift emphasis and improve on current performance levels
}

\author{
L.P. Krüger \\ Centre for Business Management, University of South Africa, P.O. Box 392, Pretoria, 0003 Republic of South Africa
}

Received October 1997

\begin{abstract}
The findings of an empirical research project show that the majority of so-called large South African manufacturers acknowledge that manufacturing-based strategies enhance the competitive capabilities and advantages of their firms and that this contributes to long-term, superior business performance and success. They also recognize that superior manufacturing capabilities will be prerequisites for the improvement on both their national and international competitive positions in the future. To better their positions in these markets, the manufacturers need to shift their emphasis (in order of priority) to: (1) high quality, low cost and high dependability, all of priority number (1); (2) high speed; and (3) high flexibility. They also need to improve on their current performance levels in all of these strategic manufacturing priorities by an average of between $20 \%$ and $30 \%$.
\end{abstract}

\section{Introduction}

South African businesses will face unprecedented opportunities (as well as threats) in the future. Following this country's most remarkable political transformation, which culminated in its first non-racial, democratic election being held towards the end of April 1994, since then its businesses have unequivocally entered the international competitive arena as fully normalized players. South African businesses should (or probably have already) realize(d) that it is one thing to compete against known local competitors in familiar regions but quite another to succeed against unknown international challengers from unfamiliar territories. It is not simply a question of how South African businesses will manage to compete with their products and services in various international markets, but also (and perhaps even more difficult to answer), how these businesses will deal with the unpredictable impact of international businesses entering the South African marketplace. Thus South African businesses - whether they voluntarily choose to enter the global competitive marketplace directly, or are involuntarily exposed to the presence of international competitors in their traditional domestic markets - all have to re-examine their business (or corporate) strategies if they are to defend and improve on their current business performance.

In a research project conducted by Krüger during 1996, which limited its focus to South African businesses currently operating in the manufacturing sector, it was argued that the way to deal with the competitive forces emerging from their new exposure to and participation in the international business environment, was to increase the use of manufacturingbased strategies' (those emphasizing certain strategic manufacturing priorities such as low cost, high quality, greater flexibility, speed and dependability). This, it was further argued, would enhance their competitive capabilities and advantages, which are essential ingredients for achieving long-term, superior business performance and success.

This article, which reports some of the empirical findings of the above-mentioned research project, first describes the theoretical background and then gives details of the research design and methodology. After the presentation of the research results, a number of conclusions are drawn and recom- mendations made for South African manufacturers concerning what the proposed future emphasis and performance levels should be in terms of their strategic manufacturing priorities.

\section{Theoretical background Introduction}

In this section, the author reviews the emergence of manufacturing-based strategies and their potential to enhance the competitive capabilities of a business for achieving longterm, superior business performance and success, the terminology or different 'labels' used to describe strategic manufacturing priorities and the wide range or the many different types of such priorities.

Emergence of manufacturing-based strategies and their potential to enhance the competitive capabilities of a business

Hayes \& Wheelwright (1984: 396) proposed a four-stage model which illustrates the evolution of manufacturing's strategic role. These stages, according to Slack, Chambers, Harland, Harrison \& Johnston (1995: 50-52), highlight the increased competitive role and progressive contribution of the manufacturing function in a business. The stages range from the largely negative stage one of internal neutrality (captioned by the phrase 'avoid or stop making mistakes'), to stage two of external neutrality (phrased 'being among the best'), to the more positively oriented stage three of being internally supportive (phrased 'to be clearly the best'), and finally, to stage four of being externally supportive (phrased 'sustain superiority through manufacturing-based advantages'). In stage four, where manufacturing is a central element in the competitive strategy of the business, it not only develops appropriate resources and implements the competitive strategy, but also becomes the long-term driver of the overall business strategy.

Crowe \& Nuño (1991: 88) also refer to the progressive contribution of manufacturing stratcgies. They argue that for many years, the traditional role of manufacturing was simply to manufacture products in response to orders from the marketplace. This independent-market, dependent-manufacturing view (typically Hayes \& Wheelwright's [1984] stages one or 
two), however, did not provide the opportunity for the adoption of manufacturing-based strategies through which competitive advantages could be sought for enhancing the competitive position of a business. These authors then observe that over the last two decades consensus has been reached that the manufacturing function of a business must play an even larger role in the development of the overall business strategy. It should move from a position of merely reacting or seeking alignment with the market to one of helping to create the market by adding competitive advantages to the business (strategies operating at stage three and ultimately, at stage four of Hayes \& Wheelwright's [1984] model).

Zahra \& Das (1993: 90) further elucidate on this relatively new idea that manufacturing strategies should contribute to the competitive advantage of a business (which Feurer \& Chaharbaghi [1995: 15] define as 'a factor or a combination of factors which make an organization more successful than other organizations in a competitive environment') in order to achieve superiority in the marketplace. They note that a manufacturing-based strategy

'... creates and adds value by helping a firm establish and sustain a defensible competitive advantage which is the unique position an organization develops vis à vis its competitors'.

The emergence of manufacturing-based strategies as a separate but related functional component of an overall business strategy (Miller \& Roth, 1994: 285) is thus now generally accepted as an indispensable tool for both sustaining current and creating new markets by enhancing the competitive position of and adding competitive advantages to a business. The importance of such strategies for businesses primarily operating in the manufacturing sector (which is the focus of this article) is thus even more pronounced.

\section{Strategic manufacturing priorities}

Vickery, Droge \& Markland (1993: 437) note that a multiplicity of 'labels' have been applied to items such as product, volume and process flexibility, low production cost, delivery speed and dependability, reliability, durability and quality. They view these items as competitive abilities that a business should seek to acquire, sustain or improve on. Other labels or terminology often used in the literature to describe these competitive abilities include: competitive devices or methods, strategic choice attributes, competitive strategy variables, manufacturing competitive priorities, performance objectives and customer requirements. In the afore-mentioned research project and this article, the term 'strategic manufacturing priorities' is used, partly because of the inherent strategic nature of the items and also to emphasize that the focus is on manufacturing businesses.

Not only do many authors use various 'labels' or different terms to describe strategic manufacturing priorities, but they also identify many different types. For example, Miller \& Roth (1994: 289) use the term 'competitive capabilities' and identify the following eleven: low price, design flexibility, volume flexibility, conformance, performance, speed, dependability, after sales service, advertising, broad distribution and broad line. Schlie \& Goldhar (1995: 105) use the term 'generic competitive advantages which can create customer value' and identify the following eight: low price, higher quality (higher reliability and level of performance), sooner availability, better customer service, greater attractiveness, greater awareness, long-term relationships and socio-psychological-political-cultural factors. Garvin (1993: 94-96) uses the term 'disaggregated strategic priorities' and lists items in both their aggregated and disaggregated format. His list is the most comprehensive but the following examples illustrate why so many different types of strategic manufacturing priorities appear in the literature. 'Quality' is disaggregated to performance, features, reliability, conformance, durability, serviceability, aesthetics, and little variability while 'delivery' is disaggregated to accuracy, completeness, dependability, availability, speed, ease of ordering, ordering flexibility, shipment flexibility and ease of return.

Slack et al. (1995: 53) argue that for any organization to succeed in the long term, it needs operations-based (or manufacturing-based) advantages. They identify a set of five performance objectives (also elsewhere referred to as competitive factors) which operations (or manufacturing) management should try to achieve for the business to gain an operations-based advantage, and further, for it to contribute to its competitiveness. These performance objectives are: 'doing things right' (for a quality advantage), 'doing things fast' (for a speed advantage), 'doings things on time' (for a dependability advantage), 'being able to change what is done' (for a flexibility advantage) and 'doing things cheaply' (for a cost advantage).

It should be clear that a wide range or many different types of strategic manufacturing priorities appear in the literature. To meaningfully determine on which strategic manufacturing priorities South African manufacturers placed their current, and should place future emphasis, it was necessary to narrow down the potential number of items considerably. This was not done before the issue of trade-offs between the items had first been considered in conjunction with the earlier discussed notion of stages three or four (Hayes \& Wheelwright, 1984) manufacturing strategies.

\section{Arguments against or for trade-offs}

Collins \& Schmenner (1993: 443), Schonberger \& Knod (1991: 67) and others, argue that no trade-offs can or should be made between different strategic manufacturing priorities. They note that world-class manufacturers are recognized for their excellence in providing customers with good quality products at low cost, delivering both rapidly and frequently, and being flexible. These attributes are thus regarded as 'givens' without which businesses cannot hope to compete.

Crowe and Nuño (1991: 89), Garvin (1993: 87) and others, however, argue that some form of a trade-off between different strategic manufacturing priorities is a necessary step. More specifically, Hayes \& Pisano (1994: 78) argue that in turbulent environments, the goal of strategies is not the same as in stable environments. In these environments the goal should rather be strategic flexibility. Their concept follows in the footsteps of the idea of focussed factories where it is argued that no single organization can do all things equally well. For example, one plant cannot provide equally well for a price-driven market and for a market where a premium is paid for high quality and customized features. Because of the existence of the product-process life cycle. the relative 
importance of competitive priorities will automatically shift and this will have important implications for manufacturing. These authors thus argue that the manufacturing function of a business should have the capability to 'switch gears'.

Referring back to the notion of 'operations-based' advantages, Slack et al. (1995:86) point out that in certain circumstances some of the performance objectives (or priorities of the different competitive factors) may be more or less important to a particular business. According to them, a useful way of determining the relative importance, is to distinguish between what Hill (1985: 49-51) refers to as 'order-winning' and 'qualifying' factors. While the latter refers to factors which are not seen as major determinants for winning business as the first are, they do represent aspects of competitiveness where the performance of the business must be above a particular level to even be considered by a customer. Both these two sets of factors, according to Russell \& Taylor (1995: 16), form part of a stage three or four manufacturing strategy (Hayes \& Wheelwright, 1984), which is also seen by them as the 'ideal' manufacturing strategy stages. Apart from the influence of the initial strategic focus in terms of 'orderwinning' of 'qualifying' factors, Slack et al. (1995) also argue that the relative priority of the business' performance objectives will further be influenced by (1) its customers' requirements, (2) what its competitors are doing, and (3), as pointed out earlier, the stage of its products in their life cycle.

However, while not ignoring the criticism's warning against trade-offs, the view advocated by Slack et al. (1995) and others was followed. In this regard the perceived value of their identified performance objectives (referred to as strategic manufacturing priorities in the research) was determined for the different businesses included in the research population. Not only were they asked to indicate their current strengths and/or weaknesses in each of the strategic manufacturing priorities, but they were also asked to predict the future importance of these priorities, first, for competing against local (or national) competitors, and secondly, for competing against international competitors.

\section{Research design and methodology}

\section{Conceptual research framework}

Figure 1 illustrates the conceptual research framework, which was designed to examine the use of strategic manufacturing priorities by South African manufacturers for enhancing their competitive capabilities and advantages to achieve long-term, superior business performance and success. As indicated, the framework has four major decision points which entail determining:

1. The present (and future potential) contribution of manufacturing strategies to achieve long-term, superior business performance and success and the future importance of superior manufacturing capabilities to better compete against national and international competitors.

2. The current strengths and/or weaknesses of South African manufacturers in terms of strategic manufacturing priorities such as high quality, low cost, high speed, flexibility and dependability.

3. The future importance of the listed strategic manufacturing priorities to better compete against both national and international competitors.

\begin{tabular}{|c|c|c|}
\hline \multicolumn{3}{|c|}{$\begin{array}{c}\text { Strategic manufacturing priorities } \\
\text { Major decision points } 1 \text { to } 4\end{array}$} \\
\hline Contribution & Current strength/weakness & Future importance \\
\hline 1 & 2 & 3 \\
\hline Presently: & \multirow[t]{2}{*}{$\begin{array}{c}\text { Quality } \\
\text { Cost } \\
\text { Speed } \\
\text { Dependability } \\
\text { Flexibility }\end{array}$} & $\begin{array}{c}\text { Nationally } \\
\text { Quality } \\
\text { Cost } \\
\text { Speed } \\
\text { Dependability } \\
\text { Flexibility } \\
\end{array}$ \\
\hline In future: & & $\begin{array}{c}\text { Internationally } \\
\text { Quality } \\
\text { Cost } \\
\text { Speed } \\
\text { Dependability } \\
\text { Flexibility } \\
\end{array}$ \\
\hline \multirow[t]{2}{*}{$\begin{array}{l}\text { 3-point scale: } \\
\text { (Yes/Not sure/No) }\end{array}$} & $\begin{array}{c}\text { 5-point scale } \\
\text { from very weak to very } \\
\text { strong }\end{array}$ & $\begin{array}{c}\text { 5-point scale } \\
\text { from not important to very } \\
\text { important }\end{array}$ \\
\hline & $\begin{array}{r}4 \\
\text { Areas for change in emph } \\
\text { (Compare }\end{array}$ & $\begin{array}{l}\text { lasis and/or improvement } \\
2 \text { with 3) }\end{array}$ \\
\hline
\end{tabular}

Figure 1 Conceptual research framework

4. The areas in which these businesses need to shift their emphasis and/or improve on their current performance to better compete against national and international competitors.

\section{Research population}

The research population encompassed individuals who (1) held managerial posts in a South African-based manufacturing business; (2) where the company or business employed more than 500 people; (3) was located or situated in all geographical regions in South Africa; and (4) in any one of all the SIC (Standard Industry Code) category manufacturers (that is food and beverages, textiles and clothing, wood products and furniture, paper and printing, chemical and plastic products, pottery and glass, iron and steel, fabricated metal products).

The names and addresses of 639 companies/business, that complied with the above definition of the research population, was identified through the industrial database of the $\mathrm{Bu}$ reau of Marketing Research (BMR) of the University of South Africa (Unisa).

\section{Data-collection procedures}

On the basis of the major decision points of the conceptual research framework (see the first part of this section), a questionnaire was compiled and posted to all the businesses of the research population. Each questionnaire had a covering letter addressed to the Managing Director in which further details of the purpose and nature of the research project were given. One hundred and thirty four completed questionnaires were 
returned, which represented a response rate of $20.8 \%$. This response rate is similar to other reported survey research by mail questionnaires where returns of less than $40 \%$ are common (Kerlinger, 1986: 380). While the response rate that was obtained is lower than what was hoped for and could limit the extent of valid generalizations, there is no reason to believe that a particular bias occurred. Rather it was a question of time (note that the respondents work in private companies where time is normally at a premium) and/or respondent fatigue (due to the many mail surveys being conducted at the same time) and/or genuine non-interest in the topic of the research.

The research strategy selected was the survey method. Because of the relatively simple nature of the questions, the questionnaire was not subjected to a formal pretest. Instead an informal pretest was done by consulting fellow colleagues on the clarity of questions and ease of use for later statistical analysis. On the basis of feedback obtained through the informal pretest, the original questionnaire was revised and included changes to its structure, wording and general appearance. In this case, the purpose of the informal pretest was thus to improve on the eventual accuracy of responses (or reliability of the questionnaire) (Kerlinger, 1986: 405, 415) and on the construct validity of the measuring instrument, the questionnaire itself (Kerlinger, 1986: 420).

\section{Research results}

a. Present contribution of manufacturing strategy towards long-term, superior business performance and success

The results, which reflect the present contribution of the manufacturing strategy to achieving long-term, superior business performance and success, are presented in Table 1. A total of $81 \%$ of the respondents believed that the manufacturing strategy of their company definitely contributed to its longterm business performance and success. A small percentage $(8 \%)$ of the respondents completely disagreed with this view while $11 \%$ were unsure.

b. Future importance of superior manufacturing capabilities to improve the national and international competitive position of business

The results, which reflect the future importance of superior manufacturing capabilities to improve the national and international competitive position of the businesses, are presented in Table 2. A large majority of the respondents (98\%) believed that the manufacturing capabilities of their company would become more important to better compete against

Table 1 Frequency table of contribution of manufacturing strategy to enhance long-term, business performance and success

\begin{tabular}{ccccc}
\hline Contribution & Yes & Not sure & No & Total N \\
\hline $\mathrm{N}$ & 107 & 15 & 10 & 132 \\
$\% \mathrm{~T}$ & $81.1 \%$ & $11.4 \%$ & $7.5 \%$ & $100 \%$ \\
$\overline{\mathrm{x}} \mathrm{s}$ & & & & 1.2700 .590 \\
\hline
\end{tabular}

$\mathrm{N}=$ frequency; $\% \mathrm{~T}$ = percentage of total;

$\bar{x}=$ average; $S=$ standard deviation
Table 2 Frequency table of future importance of superior manufacturing capabilities to compete nationally and internationally

\begin{tabular}{ccccc}
\hline Future importance & Yes & Not sure & No & Total N \\
\hline $\mathrm{N}$ & 127 & $\mathrm{I}$ & 2 & 130 \\
$\% \mathrm{~T}$ & $97.7 \%$ & $0.8 \%$ & $1.5 \%$ & $100 \%$ \\
$\overline{\mathrm{x}} \mathrm{s}$ & & & & 1.0400 .260 \\
\hline
\end{tabular}

$\mathrm{N}=$ frequency; $\% \mathrm{~T}$ = percentage of total;

$\overline{\mathrm{x}}=$ average; $\mathrm{S}=$ standard deviation

national and international competitors in the future. Only about $1 \%$ of respondents disagreed completely, while $1 \%$ were also unsure.

It should be noted that a higher proportion of respondents supported the belief that superior manufacturing capabilities would become more important in the future than those who supported the idea that their company's manufacturing strategy did contribute to its long-term, superior business performance and success. This movement towards higher support was confirmed as statistically significant with the aid of the non-parametric Wilcoxon matched-pairs signed ranks test (see Table 9).

\section{c. Current strength and/or weakness of strategic manu- facturing priorities}

The results, which reflect the current strength and/or weakness of the strategic manufacturing priorities listed, are presented in Table 3.

On the basis of the calculated weighted average scores, the rank order for the current strength and/or weakness of the

\begin{tabular}{|c|c|c|c|c|c|}
\hline $\begin{array}{l}\text { Current } \\
\text { strength }\end{array}$ & $\begin{array}{l}\text { Quality } \\
\text { N \% T }\end{array}$ & $\begin{array}{r}\text { Cost } \\
\mathrm{N} \% \mathrm{~T} \\
\end{array}$ & $\begin{array}{l}\text { Speed } \\
\mathrm{N} \% \mathrm{~T} \\
\end{array}$ & $\begin{array}{c}\text { Dependability } \\
\mathrm{N} \% \mathrm{~T}\end{array}$ & $\begin{array}{c}\text { Flexibility } \\
\mathrm{N} \% \mathrm{~T}\end{array}$ \\
\hline $\begin{array}{l}\text { V.Weak } \\
n / l\end{array}$ & $00.0 \%$ & $64.5 \%$ & $2 \quad 1.5 \%$ & $00.0 \%$ & $21.5 \%$ \\
\hline $\begin{array}{l}\text { Weak } \\
n \cdot 2\end{array}$ & $53.7 \%$ & $2921.6 \%$ & $28 \quad 21.2 \%$ & $75.2 \%$ & $2720.5 \%$ \\
\hline $\begin{array}{l}\text { Neutral } \\
\text { w3 }\end{array}$ & $1612.0 \%$ & $54 \quad 40.3 \%$ & $48 \quad 36.4 \%$ & $3828.4 \%$ & $4231.8 \%$ \\
\hline $\begin{array}{l}\text { Strong } \\
w 4\end{array}$ & $8261.7 \%$ & $3727.6 \%$ & $4735.6 \%$ & $6548.5 \%$ & $5138.6 \%$ \\
\hline $\begin{array}{l}\text { V.Strong } \\
\text { w5 }\end{array}$ & $3022.6 \%$ & $86.0 \%$ & $75.3 \%$ & $2417.9 \%$ & $107.6 \%$ \\
\hline Total & $130100 \%$ & $134100 \%$ & $132100 \%$ & $134100 \%$ & $132100 \%$ \\
\hline \#Average & 4.032 & 3.090 & 3.220 & 3.790 & 3.303 \\
\hline $\mathbf{S}$ & 0.710 & 0.950 & 0.890 & 0.800 & 0.930 \\
\hline Rank* & (1) & (5) & (4) & (2) & (3) \\
\hline
\end{tabular}

$\mathrm{N}=$ frequency; $\% \mathrm{~T}=$ percentage of total; $\mathrm{wx}_{1.5}=$ weight; $\mathrm{V}$. Weak $=$ very weak; Rank = rank order, $S=$ standard deviation; V.Strong = Very strong; \#Average $=$ weighted average

* A pure mathematically derived rank order and is not necessarily statistically significant. Such a rank order can be deduced from the Wilcoxon matched-pairs signed rank test shown in Table 4. 


\begin{tabular}{|c|c|c|c|c|c|c|}
\hline Comparison & $\begin{array}{c}\text { Mean } \\
\text { rank }\end{array}$ & -Ranks & +Ranks & Ties & $\stackrel{\mathrm{N}}{\mathrm{Z}-\text { Value }}$ & $\begin{array}{c}\text { 2-Tail } \\
\mathbf{p}\end{array}$ \\
\hline$\overline{S 4(c)(Q L T Y)}$ & 53.6 & 87 & 14 & 32 & 133 & $0.0000^{*}$ \\
\hline$\leftarrow S 4(\mathrm{c})(\mathrm{COST})$ & 34.6 & & & & -7.085 & \\
\hline S4(c) (QLTY) & 49.4 & 81 & 13 & 37 & 131 & $0.0000^{*}$ \\
\hline$\leftarrow$ S4(c) (SPED) & 35.9 & & & & -6.658 & \\
\hline S4(c) (QLTY) & 35.8 & 49 & 22 & 62 & 133 & $0.0066^{*}$ \\
\hline$\leftarrow \mathrm{S} 4(\mathrm{c})(\mathrm{DPDB})$ & 36.6 & & & & -2.716 & \\
\hline S4(c) (QLTY) & 47.8 & 75 & 15 & 41 & 131 & $0.0000^{*}$ \\
\hline$\leftarrow S 4(\mathrm{c})(\mathrm{FXBT})$ & 34.1 & & & & -6.184 & \\
\hline$S 4(c)(\cos T)$ & 44.8 & 35 & 51 & 46 & 1.32 & 0.1949 \\
\hline$\leftarrow$ S4(c) (SPED) & 42.6 & & & & -1.296 & \\
\hline S4(c) $(\operatorname{CosT})$ & 40.0 & 19 & 80 & 35 & 134 & $0.0000^{*}$ \\
\hline$\leftarrow S 4(\mathrm{c})(\mathrm{DPDB})$ & 52.5 & & & & -5.986 & \\
\hline S4(c) $(\operatorname{COST})$ & 49.5 & 36 & 59 & 37 & 132 & 0.0648 \\
\hline$\leftarrow S 4(c)(F X B T)$ & 47.1 & & & & -1.845 & \\
\hline S4(c) (SPED) & 31.5 & 13 & 69 & 50 & 132 & $0.0000^{*}$ \\
\hline$\leftarrow S 4(c)(D P D B)$ & 43.4 & & & & -5.973 & \\
\hline S4(c) (SPED) & 36.3 & 33 & 39 & 59 & 131 & 0.5115 \\
\hline$\leftarrow S 4(\mathrm{c})(\mathrm{FXBT})$ & 36.7 & & & & -0.657 & \\
\hline S4(c) (DPDB) & 42.3 & 67 & 16 & 49 & 132 & $0.0000^{*}$ \\
\hline$\leftarrow S 4(\mathrm{c})(\mathrm{FXBT})$ & 40.6 & & & & -4.965 & \\
\hline
\end{tabular}

$\mathrm{N}=$ total number; $\mathrm{p}=$ probability of chance occurrence; $S_{\mathrm{x}} \leftarrow \mathrm{S}_{\mathrm{y}}=$ movement of $y$ to $x ;$ QLTY = quality; COST = cost; SPED = speed; DPDB = dependa . bility; $F X B T=$ flexibility

* Result statistically significant at 0.05 level.

Itsted strategic manutacturing priorities (in order of greater strength) was: (1) high quality, (2) high dependability, (3) high flexibility, (4) high speed, and (5) low cost. Note this rank order is purely mathematically derived and is not necessarily statistically significant. The Wilcoxon matched-pairs signed rank test, indicated the following statistically significant rank order (see Table 4): (1) high quality, (2) high dependability, and (3) high flexibility, high speed and low cost, all ranked as number (3).

\section{d. Future importance of strategic manufacturing priori- ties to better compete against national competitors}

The results, which reflect the future importance of the strategic manufacturing priorities listed to better compete against national competitors, are presented in Table 5.

On the basis of the calculated weighted average scores, the rank order for the future importance that was placed on the listed strategic manufacturing priorities (in order of greater importance) was: (1) low cost, (2) high quality, (3) high dependability, (4) high speed, and (5) high flexibility. Note this rank order is purely mathematically derived and is not necessarily statistically significant. The Wilcoxon matched-pairs signed rank test indicated the following statistically significant rank order (see Table 6): (1) low cost, high quality and dependability, all ranked as number (1), (2) high speed, and (3) high flexibility.

It should be noted that when compared to the current strengths and/or weaknesses (see research results part [c]), high quality and high flexibility achieved the same statistically significant rankings (though higher scores) in terms of future important strategic manufacturing priorities. Two serious cases in terms of a shift in strategic focus was for (a) low cost, which was rated third in terms of current strength but was perceived to be one of three most important future strategic-manufacturing priorities, and (b) high dependability, which was rated second in terms of current strength but was also perceived to be one of three most important future strategic manufacturing priorities. In both these cases, the higher scores achieved also indicated the need for improved performance levels of these priorities. Another movement where

\begin{tabular}{|c|c|c|c|c|c|}
\hline $\begin{array}{l}\text { Future } \\
\text { importance }\end{array}$ & $\begin{array}{l}\text { Quality } \\
\text { N\%T }\end{array}$ & $\begin{array}{l}\text { Cost } \\
\mathrm{N} \% \mathrm{~T}\end{array}$ & $\begin{array}{l}\text { Speed } \\
\mathrm{N} \% \mathrm{~T}\end{array}$ & $\begin{array}{l}\text { Dependability } \\
\mathrm{N} \% \mathrm{~T}\end{array}$ & $\begin{array}{c}\text { Flexibility } \\
\mathrm{N} \% \mathrm{~T}\end{array}$ \\
\hline $\begin{array}{l}\text { N.Important } \\
w /\end{array}$ & $00.0 \%$ & $00.0 \%$ & $10.8 \%$ & $00.0 \%$ & $21.5 \%$ \\
\hline $\begin{array}{l}\text { Good to have } \\
\text { w2 }\end{array}$ & $10.8 \%$ & $00.0 \%$ & $43.1 \%$ & $00.0 \%$ & $118.7 \%$ \\
\hline $\begin{array}{l}\text { Necessary } \\
w: 3\end{array}$ & $118.5 \%$ & $129.3 \%$ & $2620.5 \%$ & $1612.5 \%$ & $3426.8 \%$ \\
\hline $\begin{array}{l}\text { Important } \\
w 4\end{array}$ & $4333.3 \%$ & $3728.7 \%$ & $60 \quad 47.2 \%$ & $4938.3 \%$ & $4535.4 \%$ \\
\hline $\begin{array}{l}\text { V.Important } \\
\text { w5 }\end{array}$ & $7457.4 \%$ & $8062.0 \%$ & $3628.4 \%$ & $6349.2 \%$ & $35 \quad 27.6 \%$ \\
\hline Total & $129100 \%$ & $129100 \%$ & $127100 \%$ & $128 \quad 100 \%$ & $127100 \%$ \\
\hline \#Average & 4.473 & 4.527 & 3.993 & 4.367 & 3.789 \\
\hline $\mathbf{S}$ & 0.690 & 0.660 & 0.830 & 0.700 & 1.000 \\
\hline Rank* & (2) & (1) & (4) & (3) & (5) \\
\hline
\end{tabular}

$\mathbf{N}=$ frequency; $\% T=$ percentage of total; $w x_{1.5}=$ weight; N.Important $=$ not important; Rank $=$ rank order; $S=s t a n d a r d ~ d e-$ viation; V.Important = very important; \#Average = weighted average

* A pure mathematically derived rank order and is not necessarily statistically significant. Such a rank order can be deduced from the Wilcoxon matched-pairs signed rank test shown in Table 6. 


\begin{tabular}{|c|c|c|c|c|c|c|}
\hline Comparison & $\begin{array}{l}\text { Mean } \\
\text { rank }\end{array}$ & -Ranks & + Ranks & Ties & $\begin{array}{c}N \\
\text { Z-Value }\end{array}$ & $\begin{array}{c}2-\text { Tail } \\
\mathrm{p}\end{array}$ \\
\hline S4(d) (QLTY) & 35.7 & 31 & 38 & 60 & 129 & 0.5439 \\
\hline$\leftarrow \mathrm{S} 4(\mathrm{~d})(\mathrm{COST})$ & 34.5 & & & & -0.6069 & \\
\hline S4(d) (QLTY) & 35.0 & 60 & 10 & 57 & 127 & $0.0000^{*}$ \\
\hline$\leftarrow \mathrm{S} 4(\mathrm{~d})(\mathrm{SPED})$ & 38.4 & & & & -5.027 & \\
\hline S4(d) (QLTY) & 25.8 & 32 & 19 & 77 & 128 & 0.1242 \\
\hline$\leftarrow \mathrm{S} 4(\mathrm{~d})(\mathrm{DPDB})$ & 26.3 & & & & -1.537 & \\
\hline S4(d) (QLTY) & 42.2 & 69 & 12 & 46 & 127 & $0.0000^{*}$ \\
\hline$\leftarrow S 4(d)(F X B T)$ & 34.3 & & & & -5.878 & \\
\hline $\mathrm{S} 4(\mathrm{~d})(\mathrm{COST})$ & 40.9 & 64 & 15 & 48 & 127 & $0.0000^{*}$ \\
\hline$\leftarrow S 4(\mathrm{~d})(\mathrm{SPED})$ & 36.0 & & & & -5.083 & \\
\hline $\mathrm{S} 4(\mathrm{~d})(\mathrm{COST})$ & 33.1 & 40 & 24 & 64 & 128 & 0.0575 \\
\hline$\leftarrow S 4(\mathrm{~d})(\mathrm{DPDB})$ & 31.5 & & & & -1.899 & \\
\hline $\mathrm{S} 4(\mathrm{~d})(\mathrm{COST})$ & 44.7 & 72 & 13 & 42 & 127 & $0.0000^{*}$ \\
\hline$\leftarrow \mathrm{S} 4(\mathrm{~d})(\mathrm{FXBT})$ & 33.6 & & & & -6.095 & \\
\hline$S 4(d)(S P E D)$ & 26.0 & 10 & 49 & 68 & 127 & $0.0000^{*}$ \\
\hline$\leftarrow S 4(\mathrm{~d})(\mathrm{DPDB})$ & 30.8 & & & & -4.718 & \\
\hline S4(d) (SPED) & 32.3 & 43 & 21 & 63 & 127 & $0.0198^{*}$ \\
\hline$\leftarrow S 4(d)(F X B T)$ & 32.9 & & & & -2.331 & \\
\hline S4(d) (DPDB) & 39.6 & 66 & 10 & 51 & 127 & $0.0000^{*}$ \\
\hline$\leftarrow S 4(\mathrm{~d})(\mathrm{FXBT})$ & 31.5 & & & & -5.944 & \\
\hline \multicolumn{7}{|c|}{$\begin{array}{l}N=\text { total number; } P=\text { probability of chance occurrence; } S_{x} \leftarrow S_{y}=\text { movement of y to } x ; Q L T Y=\text { quality; COST }=\text { cos } \\
S P E D=\text { speed } ; D P D B=\text { dependability } ; F X B T=\text { flexibility }\end{array}$} \\
\hline
\end{tabular}

a current strength held a lower ranking than its future perceived importance was for high speed.

In all these cases, it appears (and this was confirmed as statistically significant with the aid of the non-parametric Wilcoxon matched-pairs signed ranks test - see Table 9) that South African manufacturers need to improve on their current performance in all of the listed strategic manufacturing priorities and increase their emphasis which is placed on low cost, high dependability and high speed to better compete against national competitors in the future.

e. Future importance of strategic manufacturing priorities to better compete against international competitors

The results, which reflect the future importance of the strategic manufacturing priorities listed to better compete against international competitors, are presented in Table 7.

On the basis of the calculated weighted average scores, the rank order for the future importance that was placed on the listed strategic manufacturing priorities (in order of greater importance) was: (1) high quality, (2) low cost, (3) high dependability, (4) high speed, and (5) high flexibility. Note this rank order is purely mathematically derived and is not necessarily statistically significant. The non-parametric Wilcoxon matched-pairs signed rank test indicated the following statistically significant rank order (see Table 8): (1) high quality, low cost and high dependability, all ranked as number (1), (2) high speed, and (3) high flexibility.
It should be noted that, when compared to the current strengths and/or weaknesses (see research results part [c]), similar outcomes for shifts in strategic focus and increased performance levels, were indicated for international competitors as in the case for national competitors (see research results part [d]). Furthermore, when directly comparing the two. the strategic manufacturing priorities achieved higher scores (indicating a greater importance) for future international competition than for national competition. This was also (with the exception of low cost) confirmed to be statistically significant with the aid of the non-parametric Wilcoxon matched-pairs signed ranks test - see Table 9).

\section{Conclusions}

Since the majority $(81 \%)$ of the respondents believe that the manufacturing strategy of their company contributes to longterm, superior business performance and success and, moreover, that $98 \%$ of them believe that superior manufacturing capabilities will become more important in the future to better compete against both national and international competitors. it is recommended that South African manufacturers:

- observe the following focus in terms of strategic manufacturing priorities (in order of priority): (1) high quality, low cost and high dependability, all of equal priority number (1), (2) high speed, and (3) high flexibility; 
Table 7 Future importance of strategic manufacturing priorities to compete better internationally

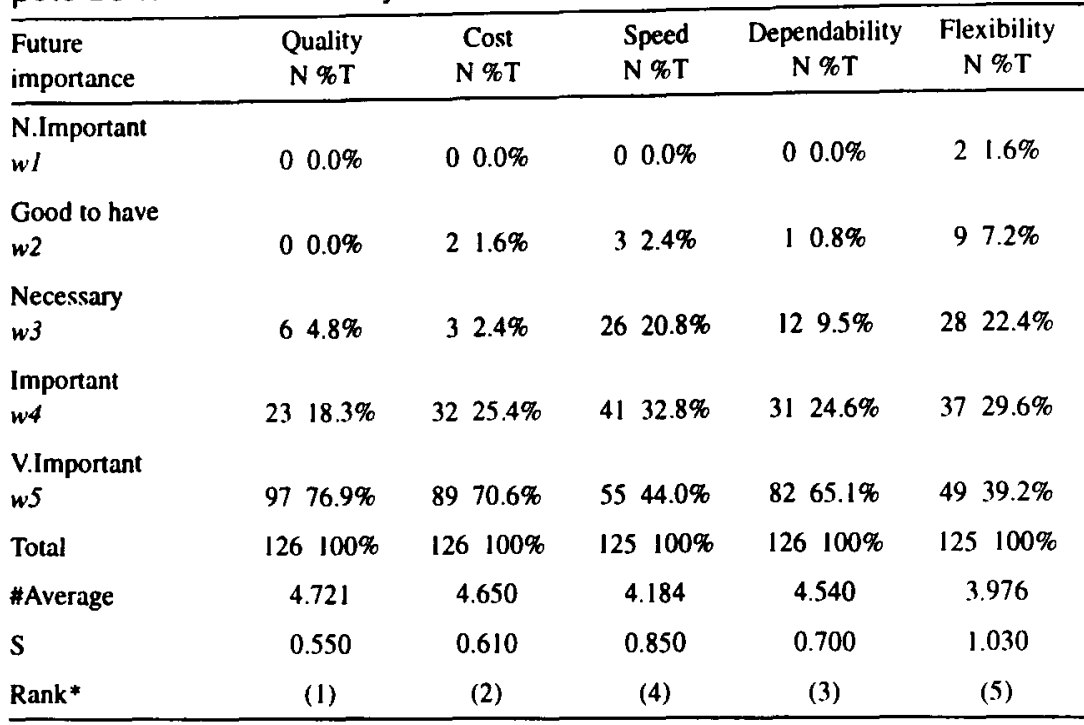

$\mathrm{N}=$ frequency; $\% \mathrm{~T}=$ percentage of total; $w x_{1.5}=$ weight; $\mathrm{N}$.Important = not important Rank = rank order; $S=$ Standard deviation; V.Important = very important; \#Average = weighted average

*A pure mathematically derived rank order and is not necessarily statistically significant. Such a rank order can be deduced from the Wilcoxon matched-pairs signed rank test shown in Table 8.

\begin{tabular}{|c|c|c|c|c|c|c|}
\hline Comparison & $\begin{array}{c}\text { Mean } \\
\text { rank }\end{array}$ & -Ranks & +Ranks & Ties & $\begin{array}{c}\mathrm{N} \\
\mathrm{Z} \text {-Value }\end{array}$ & $\begin{array}{c}\text { 2-Tail } \\
\mathrm{p}\end{array}$ \\
\hline S4(e) (QLTY) & 25.6 & 28 & 21 & 77 & 126 & 0.2963 \\
\hline$\leftarrow \mathrm{S} 4(\mathrm{e})(\operatorname{Cos} \mathrm{T})$ & 24.2 & & & & -1.045 & \\
\hline S4(e) (QLTY) & 34.0 & 56 & 9 & 60 & 125 & $0.0000^{*}$ \\
\hline$\leftarrow \mathrm{S} 4(\mathrm{e})(\mathrm{SPED})$ & 26.5 & & & & -5.450 & \\
\hline S4(e) (QLTY) & 23.2 & 26 & 14 & 86 & 126 & $0.0095^{*}$ \\
\hline$\leftarrow \mathrm{S} 4(\mathrm{e})(\mathrm{DPDB})$ & 15.5 & & & & -2.5942 & \\
\hline S4(e) (QLTY) & 37.9 & 63 & 8 & 54 & 125 & $0.0000^{*}$ \\
\hline$\leftarrow \mathrm{S} 4(\mathrm{e})(\mathrm{FXBT})$ & 21.0 & & & & -6.360 & \\
\hline$S 4(e)(\operatorname{Cos} T)$ & 31.4 & 50 & 10 & 65 & 125 & $0.0000^{*}$ \\
\hline$\leftarrow$ S4(e) (SPED) & 25.9 & & & & -4.829 & \\
\hline S4(e) (COST) & 23.0 & 27 & 17 & 82 & 126 & 0.1399 \\
\hline$\leftarrow \mathrm{S} 4(\mathrm{e})(\mathrm{DPDB})$ & 21.7 & & & & -1.476 & \\
\hline S4(e) (COST) & 35.0 & 61 & 7 & 57 & 125 & $0.0000^{*}$ \\
\hline$\leftarrow S 4(e)(F X B T)$ & 31.2 & & & & -5.875 & \\
\hline S4(e) (SPED) & 24.6 & 6 & 43 & 76 & 125 & $0.0000^{*}$ \\
\hline$\leftarrow \mathrm{S} 4(\mathrm{e})(\mathrm{DPDB})$ & 25.1 & & & & -4.626 & \\
\hline S4(e) (SPED) & 28.2 & 38 & 18 & 69 & 125 & $0.0260^{*}$ \\
\hline$\leftarrow S 4(e)(F X B T)$ & 29.2 & & & & -2.227 & \\
\hline S4(e) (DPDB) & 31.0 & 56 & 6 & 63 & 125 & $0.0000^{*}$ \\
\hline$\leftarrow$ S4(e) (FXBT) & 35.8 & & & & -5.342 & \\
\hline
\end{tabular}

- maintain their current emphasis on high quality (as one of the three most imporiant strategic manufacturing priorities) and high flexibility (as the third most important priority);
- immediately increase their emphasis on low cost and high dependability (as the other two of the three most important strategic manufacturing priorities) and high speed (as the second most important priority); 


\begin{tabular}{|c|c|c|c|c|c|c|}
\hline Comparison & Mean rank & -Ranks & + Ranks & Ties & N Z-Value & 2-Tail p \\
\hline S4(a) & 13.9 & 25 & 2 & 101 & 128 & $0.0001^{*}$ \\
\hline$\leftarrow$ S4(b) & 15.3 & & & & -3.808 & \\
\hline S4(c) (QLTY) & 34.9 & 20 & 59 & 49 & 128 & $0.0000^{*}$ \\
\hline$\leftarrow S 4(d)(Q L T Y)$ & 41.7 & & & & -4.308 & \\
\hline S4(c) $(\operatorname{CosT})$ & 21.5 & 5 & 101 & 23 & 129 & $0.0000^{*}$ \\
\hline$\leftarrow$ S4(d) $(\mathrm{COST})$ & 55.1 & & & & -8.598 & \\
\hline S4(c) (SPED) & 38.3 & 16 & 75 & 35 & 126 & $0.0000^{*}$ \\
\hline$\leftarrow$ S4(d) (SPED) & 47.7 & & & & -5.862 & \\
\hline S4(c) (DPDB) & 32.0 & 20 & 64 & 44 & 128 & $0.0000^{*}$ \\
\hline$\leftarrow$ S4(d) (DPDB) & 45.8 & & & & -5.106 & \\
\hline S4(c) (FXBT) & 30.1 & 25 & 56 & 45 & 126 & 0.0000 \\
\hline$\leftarrow \mathrm{S} 4(\mathrm{~d})(\mathrm{FXBT})$ & 45.9 & & & & -4.273 & \\
\hline S4(c) (QLTY) & 42.5 & 12 & 76 & 37 & 125 & $0.0000^{*}$ \\
\hline$\leftarrow \mathrm{S} 4(\mathrm{e})(\mathrm{QLTY})$ & 44.8 & & & & -6.025 & \\
\hline $\mathrm{S} 4(\mathrm{c})(\mathrm{COST})$ & 21.0 & 3 & 106 & 17 & 126 & $0.0000^{*}$ \\
\hline$\leftarrow \mathrm{S} 4(\mathrm{e})(\mathrm{COST})$ & 55.9 & & & & -8.872 & \\
\hline S4(c) (SPED) & 29.8 & 15 & 79 & 30 & 124 & $0.0000^{*}$ \\
\hline$\leftarrow$ S4(e) (SPED) & 50.9 & & & & -6.735 & \\
\hline S4(c) (DPDB) & 29.5 & 16 & 72 & 38 & 126 & $0.0000^{*}$ \\
\hline$\leftarrow S 4(e)(D P D B)$ & 47.8 & & & & -6.183 & \\
\hline S4(c) (FXBT) & 33.3 & 25 & 64 & 35 & 124 & $0.0000^{*}$ \\
\hline$\leftarrow S 4(\mathrm{e})(\mathrm{FXBT})$ & 49.6 & & & & -4.799 & \\
\hline S4(d) (QLTY) & 24.5 & 8 & 33 & 82 & 123 & $0.0024^{*}$ \\
\hline$\leftarrow \mathrm{S} 4(\mathrm{e})(\mathrm{QLTY})$ & 20.2 & & & & -3.039 & \\
\hline S4(d) (COST) & 22.0 & 15 & 28 & 80 & 123 & 0.0842 \\
\hline$\leftarrow \mathrm{S} 4(\mathrm{e})(\mathrm{COST})$ & 22.0 & & & & -1.727 & \\
\hline S4(d) (SPED) & 29.8 & 16 & 39 & 66 & 121 & $0.0138^{*}$ \\
\hline$\leftarrow \mathrm{S} 4(\mathrm{e})(\mathrm{SPED})$ & 27.3 & & & & -2.463 & \\
\hline S4(d) (DPDB) & 22.5 & 11 & 33 & 78 & 122 & $0.0039 *$ \\
\hline$\leftarrow$ S4(e) (DPDB) & 22.5 & & & & -2.888 & \\
\hline S4(d) (FXBT) & 29.4 & 20 & 40 & 61 & 121 & $0.0161^{*}$ \\
\hline$\leftarrow \mathrm{S} 4(\mathrm{e})(\mathrm{FXBT})$ & 31.1 & & & & -2.407 & \\
\hline \multicolumn{7}{|c|}{$\begin{array}{l}N=\text { total number; } p=\text { probability of chance occurrence; } S_{x} \leftarrow S_{y}=\text { movement of y to } x ; \text { QLTY = quality } \\
\text { COST = cost } ; \text { PPED = speed } ; D P D B=\text { dependability } ; F X B T=\text { flexibility }\end{array}$} \\
\hline Result statistic & 5 & & & & & \\
\hline
\end{tabular}

- improve on their current performance levels, between 20 and $30 \%$, in all of these strategic manufacturing priorities to better compete against both national and international competitors in the future; and

- recognize that their current performance levels in all of the strategic manufacturing priorities should improve, on average by $5 \%$ more, for international competition than for national competition.

\section{Note}

1. The term 'manufacturing-based strategy' is used to refer to a manufacturing strategy which explicitly seeks to secure compet- itive advantages for a business. Based on Hayes \& Wheelwright's (1984) four-stage model in the development of manufacturing's strategic role, such a strategy ideally operates at their stage four of being 'externally supportive' meaning that superiority is sustained through manufacturing advantages.

\section{References}

Collins, R.S. \& Schmenner, R. 1993. Achieving rigid flexibility: factory focus for the 1990s, European Management Journal, 11(4): 443-447.

Crowe, T.J. \& Nuño, J.P. 1991. Deciding manufacturing priorities: flexibility, cost, quality and service, Long Range Planning. 24(6): 88-95. 
Feurer, R. \& Chaharbaghi, K. 1995. Strategy development: past, present and future. Management Decision, 33(6): 11-21.

Garvin, D.A. 1993. Manufacturing strategic planning, California Management Review, 35: 85-106.

Hayes, R.H. \& Wheelwright, S.C. 1984. Restoring our competitive edge: competing through manufacturing. New York: Wiley.

Hayes, R.H. \& Pisano, G.P. 1994. Beyond world-class: the new manufacturing strategy, Harvard Business Review, 72: 77-86.

Hill. T. 1985. Manufacturing strategy: the strategic management of the manufacturing function. Basingstoke: Macmillan.

Kerlinger. F.N. 1985. Foundations of behavioral research. 3rd edition. New York: Holt, Rinehart \& Winston.

Krüger, L.P. 1996. Strategic manufacturing priorities for South African manufacturers. Pretoria: Centre for Business Management, University of South Africa. Published research report.

Miller, J.G. \& Roth, A.V. 1994. A taxonomy of manufacturing strategies. Management Science, 40(3): 285-304.

Pearce. J.A. II \& Robinson, R.B. Jr. 1985. Strategic management: strategy formulation and implementation. 2nd edition. Homewood, IL: Irwin.

Porter, M.E. 1980. Competitive strategy. New York: Free Press.

Russell, R.S. \& Taylor, B.W. III. 1995. Production and operations management: focusing on quality and competitiveness. Englewood Cliffs, NJ: Prentice-Hall.

Schellenberg, D.S. 1983. Issues in strategy implementation: the effect of congruence among strategy, structure, and managerial per. formance criteria on organizational performance. Indiana University, Graduate School of Business. Ann Arbor, Michigan: University Microfilms International. Published doctoral dissertation.

Schlie, T.W. \& Goldhar, J.D. 1995. Advanced manufacturing and new directions for competitive strategy, Journal of Business Re. search, 33: 103-114.

Schonberger, R.J. \& Knod, E.M. Jr. 1991. Operations management: improving customer service. 4th edition. Homewood, IL: Irwin.

Slack, N., Chambers, S., Harland, C., Harrison, A. \& Johnston, R. 1995. Operations management. London: Pitman.

Vickery, S.K., Droge, C. \& Markland, R.E. 1993. Production competence and business strategy: do they affect business performance? Decision Sciences, 24(2): 435-455.

Zahra, S.A. \& Das, S.R. 1993. Building competitive advantage on manufacturing resources, Long Range Planning, 26(2): 90-100. 